\title{
Impact of COVID-19 Pandemic on the Management of Blood Supply and Demand in Turkey
}

\author{
COVID-19 Pandemisinin Türkiye'deki Kan Kaynak \\ ve ihtiyacı Üzerine Etkisi
}

\begin{abstract}
Objective: Coronavirus disease(COVID-19) rapidly spread worldwide after its first report in December 2019, in China. This spread drastically reduced the number of blood donations, thereby creating a shortage at blood banks in the whole world. Turkish Red Crescent (TRC) is the only legal authority that organizes collection, production, storage and distribution of blood and blood products in Turkey. Only in case of emergency TRC gives permanent permission to hospitals; for collecting blood and producing its components through their own transfusion centers. This report describes how the COVID-19 impacted blood supplies of TRC and hospital demands in Turkey with an aim to improve the management of blood supply and demand during the COVID-19 and future pandemics.

Method: A cross-sectional study was conducted within a period of nine months from November 1, 2019 to July 31, 2020. Data were retrospectively obtained from donor attendance and blood inventory records of TRC and included; 1) the number of donated units of apheresis platelet concentrates (APC) and blood to TRC, 2) the number of units of APC and erythrocyte suspensions (ES) supplied by the hospitals themselves, 3) the number of units of APC and ES supplied to hospitals by TRC (APCH and ESH). The periods before (first period) and after (third period) emergence of COVID-19 outbreak in Turkey were compared.

Results: An increase of $52 \%$ in the number of APC donations, but a decrease of $22 \%$ in the number of blood donations (NBDs) were detected in the third period compared to the first one. Mean APCH values were $7081 \pm 550$ and $5121 \pm 55$ units in the first and third periods, respectively. The mean ESH values in the first, and third periods were $873 \pm 326$, and $3694 \pm 3143$ units.

Conclusion: It is obvious that we have learnt many lessons from the COVID-19 pandemic, like how to face challenges in maintaining the balance between blood demand and blood supply. Utilizing media to encourage donors and implementation of Patient Blood Management on national and institutional levels may be some of the key components of a comprehensive strategy. The collaboration of Ministry of Health, TRC and hospitals was successful in securing a balance between blood supply and demand in Turkey, on which COVID-19 pandemic impacted significantly.
\end{abstract}

Keywords: Transfusion, blood donation, blood supply chain, COVID-19, Turkish red crescent, patient blood management

öz

Amaç: Coronavirüs Hastalığı (COVID-19), Aralık 2019'da, Çin'deki ilk bildiriminin ardından hızla tüm dünyaya yayıldı. Bu yayılım kan bağışlarını oldukça azalttı ve kan bankalarında açığa neden oldu. Türk Kızılayı (TRC) Türkiye'deki kan ve kan bileşenlerinin toplanması, üretimi, depolanması ve dağıtımını organize eden tek yasal otoritedir. TRC sadece acil durumlarda, geçici olarak, hastanelere kendi transfüzyon merkezleri aracılığıly kan toplama ve bileșenlerini üretme iznini vermektedir. Bu yazı; COVID-19 ve gelecekteki pandemiler sırasında kan kaynak ve ihtiyaçlarının yönetiminin gelistirilmesi amacıyla, COVID-19'un TRC'nin kan kaynakları ve hastanelerin kan ihtiyaçlarına etkilerinden bahsetmektedir.

Yöntem: 1 Kasım 2019 ve 31 Temmuz 2020 arasındaki dokuz aylık sürede kesitsel bir çalışma yapıldı. Veriler TRC'nin donör ve kan kayıtlarından retrospektif olarak elde edilmis olup; 1) TRC'ye bağışlanan aferez trombosit (APC) ve kan ünite sayısını, 2) hastanelerin ürettiği $A P C$ ve eritrosit suspansiyonu (ES) ünite sayısını (APCH ve ESH), 3) TRC tarafından hastanelere sağlanan APC ve ES ünite sayısını içermektedir. COVID-19'un Türkiye'de saptanmasından önceki (birinci) ve sonraki (ücüncü) dönemler kıyaslandı.

Bulgular: Üçüncü dönemde, birinci dönemle kıyaslandığında; APC bağışlarında 52\% artma, kan bağışlarında $22 \%$ azalma tespit edildi. Ortalama $A P C H$ birinci ve üçüncü dönemde sırasıyla $7081 \pm 550$ ve $5121 \pm 255$ üniteydi. Ortalama ESH birinci dönemde $873 \pm 326$ üniteyken, üçüncü dönemde $3694 \pm 3143$ üniteydi.

Sonuç: COVID-19 pandemisinden, kan ihtiyaç ve kaynakları arasındaki dengeyi sağlamadaki zorluklarla nasıl yüzleşebileceğimiz gibi birçok dersler aldığımız açıktır. Vericileri cesaretlendirmede medyanın kullanımı ve Hasta Kan Yönetimi yaklaşımının ulusal ve kurumsal seviyelerde yerlesstirilmesi kapsayıc bir stratejinin anahtar bileşenleri olabilir. Türkiye'de COVID-19 pandemisinden belirgin olarak etkilenen kan ihtiyaç ve kaynak dengesini korumada; Sağlık Bakanlığı, TRC ve hastanelerin işbirliği başarılı olmuştur.

Anahtar kelimeler: Transfüzyon, kan bağışı, kan kaynak zinciri, COVID-19, Türk kızılayı, hasta kan yönetimi

(C) Telif hakkı Anestezi ve Reanimasyon Uzmanları Derneği. Logos Tıp Yayıncılık tarafindan yayınlanmaktadır. Bu dergide yayınlanan bütün makaleler Creative Commons 4.0 Uluslararası Lisansı ile lisanslanmıştır.

(c) Copyright Anesthesiology and Reanimation Specialists' Society. This journal published by Logos Medical Publishing. Licenced by Creative Commons Attribution 4.0 International (CC)
Received/Geliş: 07 April 2021 Accepted/Kabul: 09 June 2021 Publication date: 16 July 2021

Cite as: Tezcan B. Impact of COVID-19 pandemic on the management of blood supply and demand in Turkey. JARSS 2021;29(3):172-7.

Büşra Tezcan

Ankara Şehir Hastanesi, Yoğun Bakım Kliniği,

Ankara, Türkiye busraytezcan@yahoo.com ORCID: 0000-0001-8914-0234 


\section{INTRODUCTION}

Severe acute respiratory syndrome coronavirus 2 (SARS-CoV-2) rapidly spread worldwide after its first detection in December 2019, in China ${ }^{(1)}$. In Turkey the first confirmed case was registered on March 11, 2020 in a male patient who had recently traveled to Europe. As of July 31, 2020 over 230.000 positive cases were documented throughout Turkey. The spread of coronovirus disease (COVID-19) and following lockdown has drastically reduced the number of blood donations, thereby creating a shortage at blood banks in Turkey as well as in the whole world $(2,3)$.

Turkish Red Crescent (TRC) is an important and integral part of the Turkey's national health care system which provides $86 \%$ of blood supply in Turkey by canalizing the humanitarianism of Turkish people into this area. It meets the blood demand of 1102 hospitals out of 1121 throughout Turkey ${ }^{(4)}$. This report describes how the COVID-19 disease impacted blood supplies of TRC and hospital demands in Turkey. It aims to improve the coordination of blood supply and demand during the COVID-19 pandemic and similar public health emergencies in the future. TRC is the only legal authority that organizes collection, production, storage and distribution of blood and blood products in Turkey ${ }^{(5)}$. There are 19 Regional Blood Centers (RBC) connected to TRC (4). On the other side; 13 hospitals serve as Temporary Regional Blood Centers (TRBC) and organize their own blood supply chain, unless the demand exceeds their supply. In such circumstances TRBC also requests help from TRC. After collection from voluntary donors through mobile blood donation vehicles or donation centers; blood is transported to the nearest RBC that produce blood components and deliver them to hospitals ${ }^{(5)}$. In case of emergency or unmet needs of the hospital; TRC gives permanent permission (for 24-48 hours) to hospitals for collecting blood and producing its components through their own transfusion centers ${ }^{(6)}$.

\section{MATERIAL and METHOD}

Turkish Red Crescent Ethical Committee provided ethical approval for this study. A cross-sectional study was conducted for a period of nine months; from November 1, 2019 to July 31, 2020. Data were retrospectively obtained from donor attendance and blood inventory records of TRC. The data included; 1 ) the number of donated units of apheresis platelet concentrates (APCs) and blood to TRC, 2) the number of units of APC and erythrocyte suspensions (ESs) supplied by the hospitals themselves, 3 ) the number of units of APC and ES supplied to hospitals by TRC. The data about ES are chosen because it may represent the number of whole blood donations. The study period was divided into three subperiods. The first subperiod covered four months before COVID-19 outbreak in Turkey (November and December 2019, January and February 2020), second period covered only March and the third period covered four months (April, May, June, July 2020) after COVID-19 outbreak. First and third periods were compared.

Data were analysed using IBM SPSS, version 25.0. Categorical variables were described using frequencies and percentages. Continuous variables were summarized as mean \pm standard deviation.

\section{RESULTS}

Overall 15.497 APC donations ( $3874 \pm 369$ units per month) and 918.707 blood donations (229.676 \pm 13.233 units per month) were made to TRC in the first period. In the third period; 23.679 APC donations (5.919 \pm 528 units per month) and 713.077 blood donations $(178.311 \pm 67.542$ units per month) were made to TRC (Figures 1, and 2). Therefore, compared to the first period we documented an increase of $52 \%$ in the number of APC donations, but a decrease of $22 \%$ in the number of blood donations (NBDs).

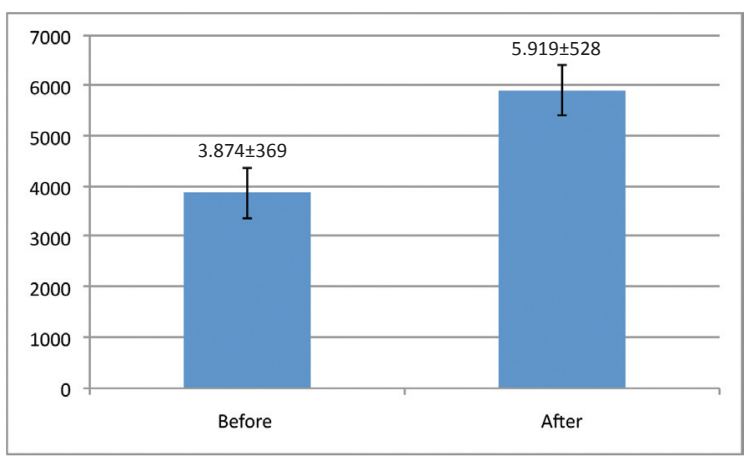

Figure 1. APC donation to TRC before and after the emergence of COVID-19 outbreak in Turkey (meantstandard deviation units per month) (Abbreviations: APC, apheresis platelet concentrates; TRC, Turkish Red Crescent). 


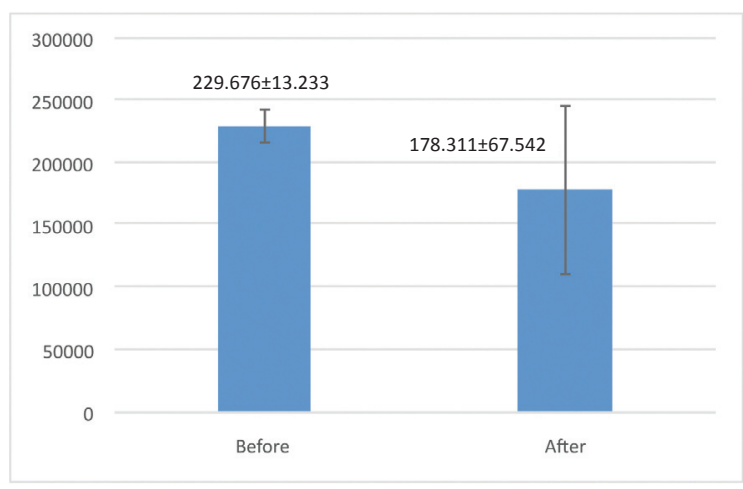

Figure 2. Blood donation to TRC before and after the emergence of COVID-19 outbreak in Turkey (mean \pm standard deviation units per month) (Abbreviation: TRC, Turkish Red Crescent).
The number of blood donations in April 2020 decreased at a greater rate (65\%) when compared with NBDs made in February 2020. The NBDs in May 2020 were comparable to NBDs in February 2020, following an awareness campaign in April 2020 (Figure 3). In may; there was an increase of $137 \%$ in NBDs compared to those in april. Moreover; the APC donations reached its maximum with 6623 units in April 2020 (Figure 4).

In April 2020; the number of units of ES supplied by hospitals (ESHs) increased by $153 \%$ compared to the ESHs in February 2020. This increment reached

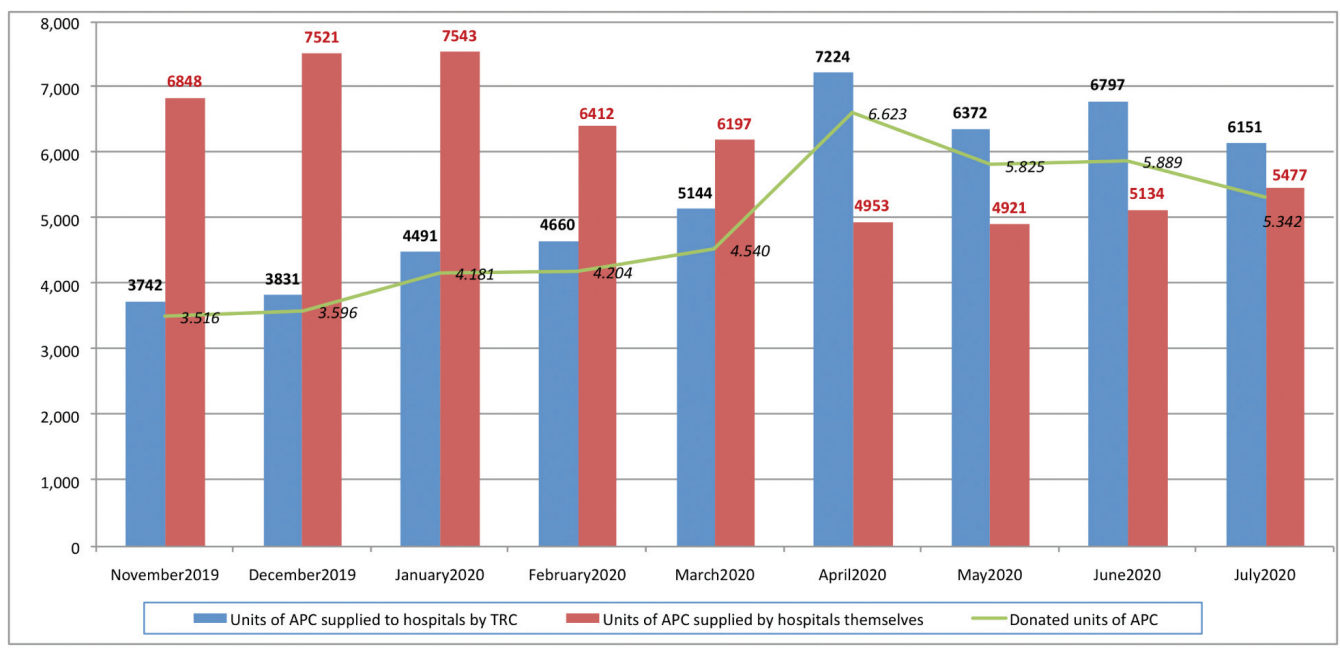

Figure 3. Number of monthly APC donations (green lines, written in italic style), APC supplied to hospitals by TRC (red bars) and APC supplied by hospitals themselves (blue bars, written in bold style) between November 2019 and July 2020 (values are expressed in units) (Abbreviations: APC, apheresis platelet concentrates; TRC, Turkish Red Crescent).

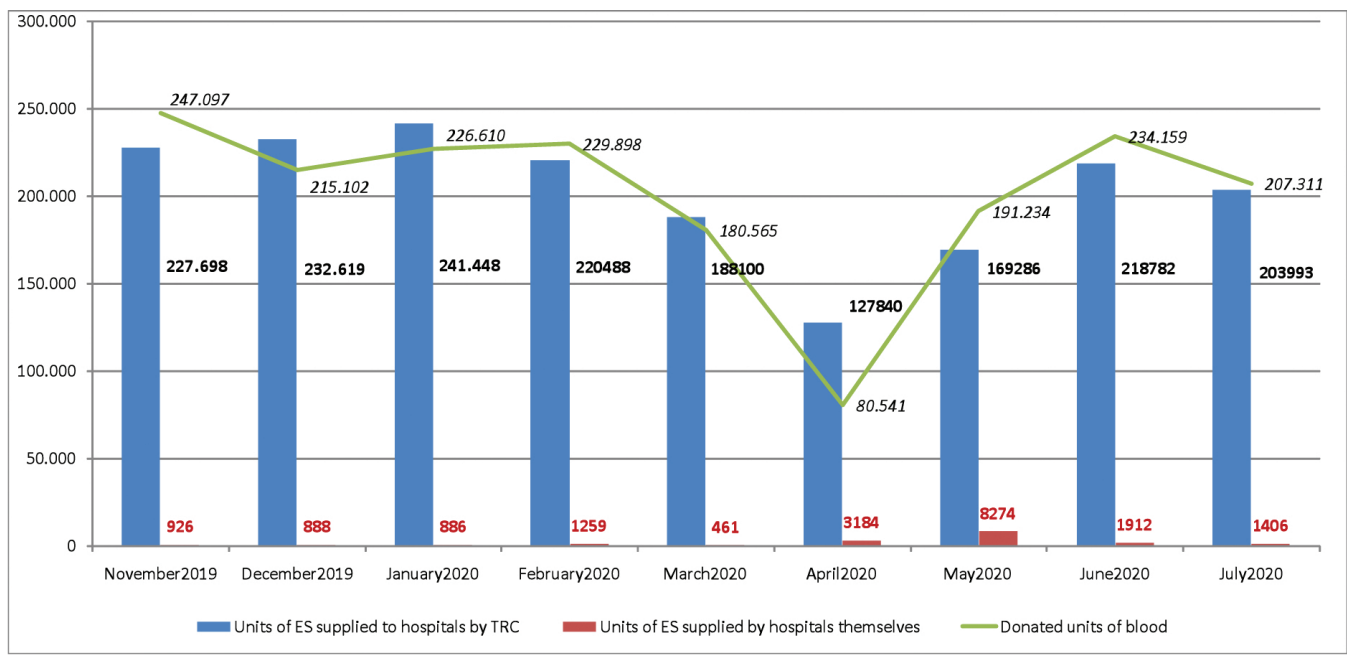

Figure 4. Number of monthly blood donations (green lines, written in italic style), blood supplied to hospitals by TRC (red bars) and blood supplied by hospitals themselves (blue bars, written in bold style) between November 2019 and July 2020 (values are expressed in units) (Abbreviations: ES, erythrocyte suspensions; TRC, Turkish Red Crescent). 
$557 \%$ in May 2020. The mean ESHs in the first period was $873 \pm 326$ units, while it was $3694 \pm 3143$ units in the third period. The mean APCs supplied to hospitals in the first period was $4181 \pm 462$ units and $6636 \pm 475$ units in the third period. The mean number of units of APC supplied by the hospitals themselves (APCH) were $7081 \pm 550$ and $5121 \pm 255$ units in the first and third periods, respectively.

\section{DISCUSSION}

Blood and blood products are essential in patient care since their transfusion may be life saving in certain circumstances. Considering that this scarce and costly resource cannot be synthesized and has a very short expiration time; routine replenishment of blood stocks is crucial ${ }^{(7)}$. Pandemics usually have significant impacts on the blood supply due to both donors' fear of exposure to the pandemic agent in a medical facility and social lockdown ${ }^{(8)}$. Governments should have plans to determine how to manage supply chain disruptions and shortages in blood products during the pandemics ${ }^{(9)}$.

Based on the experience from prior viral pandemics, COVID-19 pandemic was also expected to have a negative impact on blood bank management system activities from donation to the availability of blood and its components ${ }^{(10,11)}$. On the other side; this infection is often associated with multifactorial anemia, coagulation disorders and multiorgan failure in the severe cases ${ }^{(12)}$. Therefore many governments promoted awareness campaigns to encourage blood donation through the media at the national and local levels ${ }^{(13-15)}$. TRC also intensified publicizing this issue using media including television, social media and billboards emphasizing concerns in blood supplies. This effort resulted with an increase of $137 \%$ in NBDs in May 2020 compared with April 2020. Neverthless, mean NBDs of four months after the pandemic outbreak were still lower than that before the outbreak.

The ESH naturally increased after March 2020. In April 2020, TRC could only obtain 80.541 whole blood donations, while it supported the hospitals by 127.840 ES in April 2020. Therefore in may, hospitals had to organize medical staff and family members, friends and colleagues of patients for blood donations and ESH reached 8274 units. Other countries, including Brazil, Greece, Italy, China, Netherlands, USA and the countries in the Eastern Mediterranean Region which also faced many challenges in maintaining sustainable and adequate blood supplies, adopted various strategies and undertook actions in order to minimise the influence of pandemics on blood supplies ${ }^{(13-19)}$.

Compared to the ESH, it is obvious that most hospitals preferred to collect their own APCs even before the COVID-19 outbreak. This is probably because of difficulties in managing the storage, stocking and transport of platelet concentrates due to their shorter shelf life (only five days) ${ }^{(20)}$. When the physicians decide to transfuse APC; patient relatives are organized and APCs are collected in the transfusion center of the hospital in a more quick and easy way. If the hospitals state that this transfusion is relatively urgent, TRC approves the request to collect and process APC. After the emergence of COVID-19 disease in Turkey, this whole process should have become more time consuming and difficult for hospitals. Therefore TRC attracted more APC donors and supp-lied more units of APC to hospitals.

In accordance with the fact that blood is a valuable but perishable community resource; pandemics are chances to prompt the medical communities to adopt other solutions to maintain sustainable and adequate blood supply. Patient Blood Management (PBM) is probably the most favorable solution, which is defined as an evidence-based concept to optimize patient outcomes by clinically managing and preserving patient's own blood (6). Effective implementation of PBM is listed as one of the six goals in the recent World Health Organization Action Framework in 2020-2023 (21). Within this framework; Turkish Ministry of Health has commenced a project titled "Technical Assistance for the Improvement of Blood Transfusion ManagementSystemin Turkey" (EuropeAid/139230/ IH/SER/TR) on March 20, 2019 with support from the European Union, which will last for three years. Raising awareness of the importance of PBM in Turkey through this project has probably contributed to the successful management of blood supply chain by TRC. 


\section{CONCLUSION}

It is obvious that we have learnt many lessons from the COVID-19 pandemic to handle similar viral threats in the future. One of the corollary of this outbreak is to face challenges in maintaining the balance between blood demand and blood supply. Daily assessments of the requirements of blood banks and transfusioncenters, regular communication of the authorities and public on the need for donors, utili-zing media such as TV, radio, mewspapers, billboards and social media to encourage donors for blood donation, increasing the frequency of cleaning in the donation sites and blood-drives may be some of the key components of a comprehensive strategy. Implementation of PBM on national and institutional levels is also warranted. We should not forget that the blood has unique and precious nature with an also unique and acceptable source that is healthy, generous, voluntary adults.

COVID-19 pandemic had a profound impact on the blood supply of Turkey. The collaboration of Turkish Ministry of Heath, TRC and Turkish hospitals was successful in securing a balance between blood supply and demand.

Ethics Committee Approval: Turkish Red Crescent Blood Services General Directorate Blood Services Medical Management Directorate Ethics Committee approval was obtained (11.02.2021/5522).

\section{Conflict of Interest: None.}

Funding: None.

\section{REFERENCES}

1. Lu H, Stratton CW, Tang YW. Outbreak of pneumonia of unknown etiology in Wuhan China: the mystery and the miracle. J Med Virol. 2020;92:401-2. https://doi.org/10.1002/jmv.25678

2. Demirbilek Y, Pehlivantürk G, Özgüler ZÖ, et al. COVID19 outbreak control, example of ministry of health of Turkey. Turk J Med Sci. 2020;50:489-94. https://doi.org/10.3906/sag-2004-187

3. Cai X, Ren $M$, Chen F, et al. Blood transfusion during the COVID-19 outbreak. Blood Transfus. 2020;18:7982. https://doi.org/10.2450/2020.0076-20.

4. Annual report or Turkish Red Crescent: Directorate general of blood services 2019. https://kanver.org/ EKutuphane/FaaliyetKitaplari

5. Karadağ $\mathrm{i}$, Keskin ME, Yiğit V. Re-design of a blood supply chain organization with mobile units. Soft comput. 2021; $1-17$

https://doi.org/10.1007/s00500-021-05618-3

6. Kan ve Kan Ürünleri Yönetmeliği; Resmi Gazete Tarihi: 04.12.2008 Resmi Gazete Sayısı: 27074. https:// shgmkanhizmetleridb.saglik.gov.tr/TR-63680/kan-vekan-urunleri-yonetmeligi.html

7. Omer Yahia Al. Management of blood supply and demand during the COVID-19 pandemic in King Abdullah Hospital, Bisha, Saudi Arabia. Transfus Apher Sci. 2020;59:102836. https://doi.org/10.1016/j.transci.2020.102836

8. Shander A, Goobie SM, Warner MA, et al. Essential Role of Patient Blood Management in a Pandemic: A Call for Action. Anesth Analg. 2020;131:74-85. https://doi.org/10.1213/ANE.0000000000004844

9. Tolich D, Auron M, McCoy K, et al. Blood management during the COVID-19 pandemic. Cleve Clin J Med. 2020 Aug 7. https://doi.org/10.3949/ccjm.87a.ccc053

8. Karadağ I, Keskin ME, Yiğit V. Re-design of a blood supply chain organization with mobile units. Soft comput. 2021;1-17.

https://doi.org/10.1007/s00500-021-05618-3

9. Kan ve Kan Ürünleri Yönetmeliği; Resmi Gazete Tarihi: 04.12.2008 Resmi Gazete Sayısı: 27074. https:// shgmkanhizmetleridb.saglik.gov.tr/TR-63680/kan-vekan-urunleri-yonetmeligi.html

10. Shan H, Zhang P. Viral attacks on the blood supply: the impact of severe acute respiratory syndrome in Beijing. Transfusion. 2004;44:467-9. https://doi.org/10.1111/j.0041-1132.2004.04401.x

11. Teo D. Blood supply management during an influenza pandemic. ISBT Sci Ser. 2009;4:293-8. https://doi.org/10.1111/j.1751-2824.2009.01283.x

12. Henry BM, de Oliveira MHS, Benoit S, et al. Hematologic, biochemical and immune biomarker abnormalities associated with severe illness and mortality in coronavirus disease 2019 (COVID-19): a meta-analysis. Clin Chem Lab Med. 2020;58:1021-8. https://doi.org/10.1515/cclm-2020-0369

13. deL Barjas-Castro M, Baumgartner JE, Sales LNM, et al. Blood supply strategies facing a reference blood centre in Brazil during the COVID-19 pandemic. ISBT Sci Ser. 2020;15:344-77.

https://doi.org/10.1111/voxs.12565

14. Politis C, R,chardson C, Hassapopoulou-Matamis $H$, et al. Strategies for blood collection and optimization of the blood supply chain during the COVID-19 pandemic in Greece. ISBT Sci Ser. 2020;15:386-92. https://doi.org/10.1111/voxs.12607

15. Quaglietta A, Nicolucci A, Posata R, et al. Impact of Covid-19 epidemic on the activities of a blood centre, transfusion support for infected patients and clinical outcomes. Transfus Med. 2020;10.1111/tme.12742. https://doi.org/10.1111/tme.12742

16. Wang Y, Han W, PanL WC, et al. Impact of COVID-19 on blood services in Zhejiang province China. Vox Sang. 2020;115:502-6. https://doi.org/10.1111/vox.12931

17. Sasongko PL, van den Hurk K, Thijssen-Timmer DC: Blood supply milestones in the Netherlands in the first weeks of COVID-19. ISBT Sci Ser. 2020: 1-2. https://doi.org/10.1111/voxs.12562

18. Pagano MB, Hess JR, Tsang HC, et al. Prepare to 
B. Tezcan ve ark., Impact of COVID-19 Pandemic on the Management of Blood Supply and Demand in Turkey

adapt:blood supply and transfusion support during the first 2 weeks of the: novel coronavirus (COVID-19) pandemic affecting Washington State. Transfusion. 2020;60:908-11.

https://doi.org/10.1111/trf.15789

19. Al-Riyami AZ, Abdella YE, Badawi MA, et al. The impact of COVID-19 pandemic on blood supplies and transfusion services in Eastern Mediterranean Region. Transfus Clin Biol. 2021;28:16-24.

https://doi.org/10.1016/j.tracli.2020.11.002
20. Albdulwahab US. Blood platelet bank inventory management: an approximate dynamic programming approach. 2015. Ryerson University, Ryerson.

21. WHO action framework to advance universal access to safe, effective and quality assured blood products 2020 2023. World Health Organization. February 19, 2020. Available at: https://www.who.int/news-room/ detail/19-02-2020-who-action-framework-to-advanceuniversal-access-to-safe-effective-and-quality-assuredbloodproducts-2020--2023. Accessed April 9, 2020. 